\title{
A Review of Geo Polymer Concrete by Using Various Industrial Waste Materials
}

\author{
Bhavik kumar B. Patel ${ }^{1}$, Dr. Jayesh kumar Pitroda ${ }^{2}$ \\ ${ }^{I}$ Student of final year, M.Tech. (Construction Engineering \& Management), B.V.M. Engineering College, \\ Vallabh Vidyanagar, Gujarat, India
}

${ }^{2}$ Assistant professor, Civil Engineering Dept., B.V.M. Engineering College, Vallabh Vidyanagar, Gujarat, India

*Corresponding Author: Dr. Jayeshkumar Pitroda, Assistant Professor, Civil Engineering Department, B.V.M Engineering College, Vallabh Vidhyanagar, Gujarat, India

\begin{abstract}
Infrastructure sector in developing countries is growing very rapidly. Availability and cost of construction materials plays a vital role in maintaining this growth momentum. In the present age the waste generated from industriesis the huge concern for the environment, health, and cause for land filling. Recycling of such wastes and using them in construction materials appears to be viable solution not only to the pollution problem but also an economical option in construction. There are many choices in regard to selection of materials in any type of constructions. Due to growing interest in sustainable construction, engineers and architects are motivated to choose the materials which are more sustainable. Geo polymer concrete capable for sustainable construction is characterized by application of industrial wastes to reduce consumption of natural resources and energy and pollution of the environment. Replacement of materials over nominal concrete is what makes Geo polymer concrete more environmental friendly concrete.It contains fly ash, alkaline solution as binding material. In view of utilization of industrial waste in Geo polymer Concrete, the present paper reviews various Industrial waste materials at different levels in Geo polymer Concrete. Compressive strength of Geo polymer Concrete incorporating different waste materials is reviewed and recommendations are suggested at the outcome of the study. The reviewed approach for development of new construction material using industrial waste is useful to provide a potential sustainable source.The main objective of this investigation is to increase the strength of Geo polymer concrete and decrease the cost of Geo polymer concrete by replacing natural resourceswith various industrial waste materialssuch as waste glass powder, Fly Ash, copper slag and Steel slag, Granite slurry,bottom ash,M-Sand, Micro Silica, Nano Silica, Foundry Sand, etc. This paper describes the literature which isbased on Geo polymer concrete in which various industrial wastes such as waste glass powder, Fly Ash, Bottom Ash, Copper Slag etc., replaced by natural resources in Geo polymer concrete. This paper provides a review of research era in the area of Geo polymer concrete.
\end{abstract}

Keywords: Geo polymer Concrete, Natural Resources Replacement, Fly Ash, GGBS, Waste Glass Powder, Granite slurry, bottom ash, Copper slag, M-Sand, Micro Silica, Nano Silica, Foundry Sand, Steel Slag, EWaste

\section{INTRODUCTION}

Portland cement concrete industry has full-fledged universally in recent years.The demand for concrete as a construction material has enlarged due to enhance of infrastructure. However, production of Portland cement concrete generates problems such as carbon di oxide emission, global warming. Human activities on earth produce in considerable quantities of wastes more than 2,500 million tons per year, including industrial and agricultural wastes from rural and urban societies. This creates serious problems to the environment, health and also the land filling. Now a day the concrete is most used manmade material in the world. The Indian construction industry alone consumes approximately 400 million tons of concrete every year and the relative amount of mortar too. Therefore the demand of the concrete and the required raw materials are very high. This causes the hike in the costs of cement, fine and coarse aggregates. Quite often the shortage of these materials is also occurred. To avoid the problems like cost hike and cuts in supply of concrete and mortar, the alternate material or the partial replacements for the cement and aggregate should be developed by recycling of waste materials. This provides us the low cost, lightweight and eco-friendly construction 
products. Use of the waste materials also reduces the problem of land-filling, environmental and health concern.

Geopolymers are inorganic polymeric binding materials, developed by Joseph Davidovits in 1970.Geopolymer is a type of amorphous alumino silicate cementations material that shows the ideal properties of rock forming minerals. Davidovits proposed that an alkaline liquid could be used to react with silicon and the aluminum in a source material of geological origin. Flyash geopolymers have been prepared as geopolymer pastes, mortar and the concretes. The source materials and the alkaline liquids are the two main constituents of geopolymer. The natural minerals that are rich in silicon and aluminium are the source materials for geopolymers. The alkaline liquid are from soluble alkali metals that are sodium or potassium based. The most common alkaline liquid used in geopolymerisation is a combination of sodium hydroxide and sodium silicate. Geopolymer is a result of reaction between material containing aluminosilicate (source material) and concentrated alkaline solution.

Davidovits termed it geopolymer concrete, which is output of chemical reaction between aluminosilicate containing source materials and alkaline liquids (alkali polysilicates) results a binding gel of Si-O-Al bonds. With reference to the previous test results, its proves that geopolymer concrete has advantage over conventional concrete, in terms of mechanical strength, environmental exposure fire resistance, etc. F class fly ash, i.e low calcium fly ash when mixed with alkaline solution in presence of heat, results in more durable, efficient and environmental concrete which respect too conventional concrete. Alkali activated materials can be: (a) the high calcium materials, with ground granulated blast furnace slag; (b) the low calcium materials (Class F fly ash) and metakaolin as raw materials. Research has been done on these two systems, along with the role of activator type and alkali concentration, the prominent dosage of raw materials, the effect of admixtures, effect of curing temperature, mechanical strength, thermal strength and durability, etc. Excellent properties can be achieved from both systems, drawbacks such as setting time, high shrinkage of alkali activated slag, need of high curing temperatures and relatively long setting times of alkali activated alumina silicates, limit their practical application.

In both developed and developing countries waste management problem has already become severe. The problem is compounded by the rapidly increasing amounts of industrial wastes of a complex nature and composition. Energy plays a crucial role in the growth of developing countries like India. In the context of low availability of non-renewable energy resources coupled with the requirements of large quantities of energy for Building Materials like cement, the importance of using industrial waste cannot be underestimated. Many research organizations are doing extensive work on waste materials concerning the viability and environmental suitability. Recent researchers aimed at the conservation in the cement and the concrete industry focused on the use of Industrial waste materials such as glass powder, Bottom Ash, GGBS(Ground Granulated Blast Furnace Slag), fly ash, Steel slag, silica fumeetc in Geo polymer concrete to increase the strength of Geo polymer concrete. Many researchers have made attempts to use the Industrial waste materials to reduce the disposal problems and to improve the mechanical properties of Geo polymer concrete.

\section{Previous Research Review based on Geo Polymer Concrete by Using Various INDUSTRIAL WASTE MATERIALS}

Ganapati Naidu et al. (2012)has investigated to study strength properties of geopolymer concrete using low calcium fly ash replacing with slag in 5 different percentages.Sodium silicate $\left(103 \mathrm{~kg} / \mathrm{m}^{3}\right)$ and sodium hydroxide of 8 molarity $\left(41 \mathrm{~kg} / \mathrm{m}^{3}\right)$ solutions were used as alkalis in all 5 different mixes M1, M2, up to M5. With maximum (28.57\%) replacement of fly ash with slag (Mix no5), achieved a maximum compressive strength of 57MPa for 28 days. The same mix (Mix no5) is shown $43.56 \mathrm{MPa}$ after exposure of $500^{\circ} \mathrm{C}$ for 2 hours. Higher concentrations of GGBS result in higher compressive strength of geopolymer concrete.Mixing of G.G.B.S was tested up to $28.57 \%$, beyond that immediate setting was observed. There is no necessity of exposing geopolymer concrete to higher temperature to attain maximum strength if minimum 9\% of fly ash is replaced by GGBS. 90\% of compressive strength was achieved in 14 days. [4]

Prof. M. A. Bhosale et al. (2012) has described the mechanism of activation of a fly ash (no other solid material was used) with highly alkaline solutions and reported on the study of the processing of geopolymer using fly ash and alkaline activator with geopolymerization process. The factors that 
influence the early age compressive strength such as molarities of sodium hydroxide $(\mathrm{NaOH})$ have been studied. These studies comprise the comparison of the ratios of $\mathrm{Na}_{2} \mathrm{SiO}_{3} \& \mathrm{NaOH}$ at the values $0.39 \& 2.51$.The geopolymer paste samples were cured at $60^{\circ} \mathrm{C}$ for 1 day and keep in room temperature until the testing days and result showed that the geopolymer paste with $\mathrm{NaOH}$ concentration, compressive strength increase with molarities increases and revealed with preparation of test samples of fly ash with geopolymers of different composition in the ratio of $0.39 \& 2.51$. The samples are prepared with the different molarities such as 8,10,12,14. Case-1:For ratio $\mathrm{Na}_{2} \mathrm{SiO}_{3} / \mathrm{NaOH}=2.51$, As higher concentration in terms of molar of solutions, results in higher compressive strength of fly ash based geopolymer concrete. Case-2:For ratio $\mathrm{Na}_{2} \mathrm{SiO}_{3} / \mathrm{NaOH}=0.39$, It is observed that, when quantity of sodium silicate \& sodium hydroxide is reversed by mass, it is observed that compressive strength increases as increase in molarity. For both cases that is $1 \& 2$ compressive strength is more for oven drying as compare to specimen left in ambient temperature. Compressive strength test is performed.[5]

Mr. Bennet Jose Mathew et al. (2013)has studied the feasibility of production of geopolymer concrete using coarser bottom ash, the effect of replacement of fly ash with bottom ash at varying percentage on strength of Geopolymer concrete and the effect of curing methodology on strength of fly ash-GGBS based geopolymer concrete. Economic impact and sustainability studies were conducted on both OPC based concrete and geopolymer concrete. Bottom ash -GGBS based geopolymer concrete gave very low strength probably due to large particle size. Geopolymer concrete can be prepared at comparable cost with OPC based concrete provided transportation system for raw materials is well established. The embodied energy of fly ash- GGBS based geopolymer concrete is $40 \%$ less than that of OPC based concrete.Sodium hydroxide (39\%) and sodium silicate (49\%) together contributes a lion's share to embodied energy of geopolymer concrete while in OPC cement contributes nearly $94 \%$ of the total embodied energy. [6]

Ravindra Singh Shekhawat et al. (2013) the objective of his thesis was to investigate possibilities of utilizing LD slag by geopolymer concrete and trying explore the potential of steel slag as one of the raw material for making geopolymer concrete of M20 grade and steel slag has a lower reactivity in geopolymer system and it was used in combination with fly ash and granulated blast furnace slag. The geopolymerization behaviour has been studied using Isothermal conduction calorimeter. The geopolymer concrete developed has shown compressive strength similar to M20 grade concrete. As per expectations of achievable strength of $25 \mathrm{MPa}$, but not getting the expected strength. The maximum achieved strength after 28 days is $24.15 \mathrm{~N} / \mathrm{mm}^{2}$ and minimum of $13.45 \mathrm{~N} / \mathrm{mm}^{2}$. One of the possible reasons of this downfall in strength is because of the binder percentage in the composition.[7]

B. Rajini et al. (2014) the objective of his thesis was to study GGBS and Fly ash as a different replacement levels (FA0-GGBS100, FA25-GGBS75, FA50-GGBS50; FA75-GGBS25, FA100, GGBS0). The compressive strength and split tensile strength of geopolymer concrete respectively $54.29 \mathrm{~N} / \mathrm{mm}^{2}$ and $2.46 \mathrm{~N} / \mathrm{mm}^{2}$ is maximum for the FA0-GGBS100 irrespective of curing period. The rate of gain in compressive strength and split tensile strength of geopolymer concrete is very fast at 7 days curing period and the rate gets reduces with age.[8]

A. Rajerajeswari et al. (2014)has studied to reveal the possibility of silica fume based geopolymer concrete to find out its compressive strength by considering the parameters such as effect of $\mathrm{Na}_{2} \mathrm{Sio}_{3} / \mathrm{NaOH}$ ratio, effect of AL/SF ratio and effect of age of concrete. From the experimental investigation it was found that out of three different ratios of $\mathrm{Na}_{2} \mathrm{Sio}_{3}$, three different ratios of $\mathrm{AL} / \mathrm{SF}$, four different ages of silica fume based geopolymer concrete $\mathrm{AL} / \mathrm{SF}=0.25$ and $\mathrm{Na}_{2} \mathrm{SiO}_{3} / \mathrm{NaOH}=0.5$ yielded better gain in compressive strength. By considering the AL/SF ratio $=0.25$ there is an increase in strength of $73 \%$ for 3 to 7 days, $38 \%$ for 7 to 28 days, $15 \%$ for 28 to 56 days for all the ratios of $\mathrm{Na}_{2} \mathrm{SiO}_{3} / \mathrm{NaOH}$ ratios, Similarly by considering the $\mathrm{Na}_{2} \mathrm{SiO}_{3} / \mathrm{NaOH}=0.5$ there is an increase in strength of $84 \%$ for 3 to $7,38 \%$ for 7 to $28,15 \%$ for 28 to 56 days for all the ratios of AL/SF ratios and $60 \%$ replacements of silica fume yielded better compressive strength when compared to conventional concrete under normal curing.[9]

T.V. Srinivas Murthy et al. (2014) has studiedto produce the geo-polymer concrete, the Portland cement is fully replaced with GGBS (Ground granulated blast furnace slag) and alkaline liquids are used for the binding of materials. The curing is carried in oven, curing at $65^{\circ} \mathrm{C}$. For this study M50 concrete mix was used for experimental work and results of test show that the use of GGBS based 
geopolymer concrete increases in compressive strength, Split tensile strength and Flexural strength respectively by $13.82 \%, 18.23 \%, 30.19 \%$ as compared with conventional concrete.[10]

L. Krishnan et al. (2014)the objective of his thesis was to produce a carbon dioxide emission free cementatious material and studied the main limitations of fly ash based geopolymer concrete are slow setting of concrete at ambient temperature and the necessity of heat curing are eliminated by addition of Ground Granulated Blast Furnace Slag (GGBS) powder which shows considerable gain in strength and result of test shows that geopolymer concrete cubes gains strength within 24 hours without water curing at ambient temperature and the strength of geopolymer concrete was increased with increase in percentage of GGBS in a mix. It was observed that the mix Id F60G40 gave maximum compressive strength of $80.50 \mathrm{~N} / \mathrm{mm}^{2}$. Also the splitting tensile strength and flexural strength for the mix F60G40 was done.[11]

C. Sreenivasulu et al. (2015)has investigated at studying the mechanical properties of geopolymer concrete (GPC) using granite slurry (GS) as sand replacement. GS was replaced at different replacement levels $(0 \%, 20 \%, 40 \%$ and $60 \%)$. Fly ash and ground granulated blast furnace slag (GGBS) were used at 50:50 ratio as geopolymer binders. It is concluded that optimum replacement level $(40 \%)$ of GS can be used in place of sand. [12]

Jerusha Susan Joy et al. (2015) hasstudied to found out the effectiveness of used foundry sand as a partial replacement of fine aggregate in geopolymer concrete. $0 \%, 5 \%, 10 \%, 15 \%, 20 \%$ and $25 \%$ by weight of fine aggregate is replaced with foundry sand in this study. The silica ash - GGBS based geopolymer concrete gained strength with earlier time period through oven curing at $80^{\circ} \mathrm{C}$. The mix with $15 \%$ replacement of fine aggregate gives maximum strength of $21.33 \mathrm{~N} / \mathrm{mm}^{2}$. The optimum amount of replacement was found to be $15 \%$.[13]

JanardhananThaarrini et al. (2015) has studied the feasibility study on the manufacture of geopolymer concrete at low concentrations of alkaline solutions and lower densities and incorporating waste products like Foundry sand without compensating for the strength properties. From the preliminary studies, the replacement of Foundry sand to Natural sand is taken as 50:50. The density range was taken as $1800 \mathrm{Kg} / \mathrm{m}^{3}, 2000 \mathrm{Kg} / \mathrm{m}^{3}, 2200 \mathrm{Kg} / \mathrm{m}^{3}$ and $2400 \mathrm{Kg} / \mathrm{m}^{3}$. The percentage ratio of BA-GGBFS was selected as 0, 25, 50, 75 and 100.BA-GGBFS-FS geopolymer blocks attain sufficient strengtheven at lower molarities of $4 \mathrm{M} \mathrm{NAOH}$ solution under ambientcuring conditions which is an encouraging outcome of thiswork. As the quantity of slag increases, the compressive strengthincreases upto a $50 \%$ replacement beyond which it decreases. Geopolymer concrete absorbs less water when compared to normal concrete and shows better resistance against chloride and sulphate attack and Foundry sand upto 50\% replacement for riversand does not affect the strength of geopolymer concrete.[14]

Shalika Sharma et al. (2015) studied the change in the abrasion resistance of Geopolymer concrete was observed with the change in the curing temperature. Geopolymer concrete sample cured at $25^{\circ} \mathrm{C}$ requires 120 hours of curing whereas geopolymer concrete at high temperatures can be cured at 72 hours and abrasion resistance increases with the increase in temperature.[15]

O. M. Omar et al. (2015) has investigated the traditional testing of hardening concrete, for selected mixes of cement and geopolymer concrete. It was found that local steel slag as a coarse aggregate enhanced the slump of the fresh state of cement and geopolymer concretes. When using local Steel Slag as hundred percent substitutes for coarse aggregate recorded that the compressive strength higher than about $6 \%$ from strength of mix prepared with crashed stone as coarse aggregates in the geopolymer concrete. Higher concentration (in terms of molar) of sodium hydroxide solution results in higher compressive strength of fly ash-based geopolymer concrete, and the higher ratio of sodium silicate-to-sodium hydroxide ratio by mass, higher is the compressive strength of fly ash-based geopolymer concrete.[16]

Yagnesh Patel et al. (2015) the objective of his thesis was to the Experiment has been taken up on low calcium fly ash based geopolymer concrete having three different molar concentration of activator liquids along with different percentage of Nano silica addition. The investigations have been done by observing the compressive strength, $\%$ weight loss and $\%$ loss of compressive strength and presented the effect of addition of different proportion of Nano silica in the low calcium fly ash based geopolymer concrete. Experimental result showed that the compressive strength of low calcium fly 
ash based geopolymer concrete was increased with increase in percentage of Nano silica in a mix. The compressive strength of GPC specimens with $12 \mathrm{M}$ having $1.5 \% \mathrm{NS}$ is 1.20 times more than GPC specimens with $8 \mathrm{M}$ having $1.5 \%$ NS but marginal increase with $16 \mathrm{M}$ having $1.5 \%$ NS for 28 days. In durability test, Loss of weight due to chloride effect is decreased with increase in molarity and also minor decrease with increase in percentage of nano silica.Nano silica shows impact on compressive strength and durability properties of geopolymer concrete.[17]

Shalika Sharma et al. (2015) the objective of his thesis was to change in the compressive strength of Geopolymer concrete was observed with the change in the curing time and curing temperature. It was found that the sample of geopolymer concrete having the ratio of fly ash to alkaline liquid as 0.4 and ratio of $\mathrm{NaOH}$ to $\mathrm{Na}_{2} \mathrm{SiO}_{3}$ as 2 cured at the temperature of $25^{\circ} \mathrm{C}$ required curing time of 120 hours but still the compressive strength was very less. The samples which were cured at $60^{\circ} \mathrm{C}$ and $80^{\circ} \mathrm{C}$ required lesser curing times of 72 hours and attained greater compressive strength.[18]

Dr. I.R. Mithanthaya et al. (2015)has investigated the effect of glass powder (GP) and ground granulated blast furnace slag (GGBS) on the compressive strength of Fly ash based geopolymer concrete. The mass ratio of fine aggregate (FA) to coarse aggregate (CA) was maintained constant.The ranges of investigation parameters include GP/FA from $0 \%$ to 20\%, and GGBS/ FA from $0 \%$ to $20 \%$ with constant amount of GP. Replacement of FA by GP up to $15 \%$ is useful in increased compressive strength up to $20 \mathrm{Mpa}$. $10 \%$ replacement of FA by GP and further replacement of FA by GGBS up to $15 \%$ increases the strength of concrete up to 32Mpa. Geopolymer concrete with compressive strength of $30 \mathrm{Mpa}$ and water absorption less than $7 \%$ can be obtained using only industrial waste materials without using Sodium Silicate or heating to higher temperature. Geopolymer concrete is about $14 \%$ cheaper compared to concrete using PC.[19]

Nitendra Palankar a et al. (2015) has researched to focus on development of alternative binder materials to Ordinary Portland Cement (OPC) due to huge emissions of greenhouse gases associated with production of OPC and conducted to evaluate the performance of weathered steel slag coarse aggregates in GGBFS-FA based geopolymer concrete.GGBFS-FA geopolymer concrete with steel slag coarse aggregates are prepared by replacing natural granite aggregates at different replacement levels i.e. $0 \%, 25 \%, 50 \%, 75 \%$ and $100 \%$ (by volume) and various fresh and mechanical properties are studied and results of test indicated that incorporation of steel slag in GGBFS-FA geopolymer concrete resulted in slight reduction in mechanical strength. The water absorption and volume of permeable voids displayed higher values with inclusion of steel slag. The fatigue resistance of GGBFS-FA geopolymer concrete mixes decreased with the replacement of granite aggregates with higher contents of steel slag aggregates. GGBFS-FA geopolymer mixes with steel slag coarse aggregates recorded slightly lower compressive strength along with lower tensile strength and modulus of elasticity as compared to GGBFSFA geopolymer with granite aggregates; due to the presence of a thin layer of calcite on the aggregate surface thus leading to a weak aggregate-paste interface.[20]

P. VenkataAvanthiSailalasa et al. (2015) has described the experimental investigation carried out to develop geopolymer concrete based on alkali activated fly ash by Sodium Hydroxide with Sodium Silicate. The granite waste because of its fineness and size it can be effectively used as a replacement of sand. It was possible to achieve compressive strength $38 \mathrm{~N} / \mathrm{mm}^{2}$ for the geopolymer concrete after 8 days of casting when cured for 48 hours at $95^{\circ} \mathrm{C}$ and results of test indicated that the increase of water content of all three forms of geopolymer resulted in decrease of the compressive strength. Strength development of geopolymer at room temperature was also studied and found that only half of the compressive strength of the heat cured sample was achievable even after 28 days. Using $15 \%$ Granite powder as sand replacement and $14 \mathrm{M} \mathrm{NaOH}$ gave maximum compressive strength of 38 $\mathrm{N} / \mathrm{mm}^{2}$ and $43 \mathrm{~N} / \mathrm{mm}^{2}$ respectively 8 days and 28 days.[21]

M LeninSundar et al. (2016)has studied E-waste as a partial replacement of the fine aggregates ranging from 0 to 30 percentages, on the strength criteria of M40 of grade concrete. It has been proved that 20 percentage replacement of E-waste achieved higher strength of geopolymer concrete than the normal geopolymer concrete.[22]

P Abhilash et al. (2016) the objective of his thesis wasat the study of effect of fly ash (FA) and ground granulated blast furnace slag (GGBS) on the mechanical properties of geo polymer concrete (GPC) when they were replaced for cement at different replacement levels (FA50-GGBS50, FA75- 
GGBS25, FA100-GGBS0) using Sodium silicate $\left(\mathrm{Na}_{2} \mathrm{SiO}_{3}\right)$ and sodium hydroxide $(\mathrm{NaOH})$ solutions as alkaline activators and results of test showed that as the percentage of GGBS in the mix is increasing, mechanical properties such as compressive strength, split tensile strength and flexural strength were increasing. It is concluded that optimum replacement level (FA50 GGBS50) of Fly Ash and GGBS can be used in place of Cement.[23]

Neethu Susan Mathew et al. (2016) has studied to use supplementary cementitious materials such as fly ash and GGBFS as replacement for the cement and industrial by product such as copper slag as partial replacement for fine aggregate in concrete. The strength, durability and bond strength characteristics of fly ash and GGBFS based geopolymer concrete with and without the fine aggregate replacement have been compared. The results indicated that geopolymer concrete with $40 \%$ copper slag as fine aggregate replacement showed an improvement of $17.5 \%, 13.94 \%$ and $22.72 \%$ in the $28^{\text {th }}$ day compressive strength, splitting tensile strength and flexural strength respectively in comparison with the geopolymer concrete without copper slag, but in terms of durability of geopolymer concrete, it is found to be more water absorbent.The density increases by $4.25 \%$ and hence suitable for high density concrete. Modulus of elasticity and bond strength values of geopolymer concrete reduces by $0.4 \%$ and $4.1 \%$ respectively when copper slag replaces fine aggregate by $40 \%$. It is concluded that optimum replacement level (40\%) of copper slag can be used in place of fine aggregate by copper slag. [24]

Shriram Marathe et al. (2016) has investigated that the glass powder is varied percentage of $0 \%, 5 \%, 10 \%, 15 \%$ and $20 \%$ means $0 \%$ to $20 \%$ replacement of fly ash by glass powder and the percentage of GGBS is varying form of $5 \%, 10 \%, 15 \%$ and $20 \%$ means $5 \%$ to $20 \%$ replacement of GGBS by glass powder. It is found that GP5 has attained the maximum compressive strength of 7.77 $\mathrm{N} / \mathrm{mm}^{2}$ for 7 days and $23.33 \mathrm{~N} / \mathrm{mm}^{2}$ for 28 days. Hence up to $5 \%$ replacement of glass powder with fly ash is acceptable. It is found that GGBS5 has attained the maximum Split tensile strength of 3.11 $\mathrm{N} / \mathrm{mm}^{2}$ for 28 days. Hence up to 5\% replacement of GGBS with fly ash is acceptable. The maximum split tensile strength of $2.26 \mathrm{~N} / \mathrm{mm}^{2}$ at $20 \%$ addition of GGBS, at the age of 7days curing period. It is found that $15 \%$ GGBS has attained the maximum compressive strength of $28 \mathrm{~N} / \mathrm{mm}^{2}$ for 28 days and observed that as a 7 days compressive strength of $11.55 \mathrm{~N} / \mathrm{mm}^{2}$ of cube specimen is obtained at the 20\% addition of GGBS it gives the maximum compressive strength.[25]

R. B. Sheral et al. (2016) has observed from test results that partial and full replacement of cement with GGBS \& fly ash is successfully possible whereas strength of geo-polymer concrete \& conventional concrete shows similar behaviour and noted that cost of geo-polymer concrete \& conventional concrete is also nearly same.Compressive strength observed from compressive strength test \& Non-Destructive Rebound Hammer Test shows similar behaviour. Quality of concrete tested from Non-Destructive ultra-sonic pulse velocity test shows good performance for both geo-polymer concrete as well as conventional concrete. Cost analysis is carried out to know economy of present work and observed that cost required for conventional concrete, geo-polymer concrete (fly ash $60 \%$ and GGBS 40\%) \& (fly ash 30\%, GGBS 30\% \& cement 40\%) is nearly same.[26]

M BalaVinayag et al. (2016) the objectiveof his thesis was to utilization of waste material as well as produces an alternative material for cement concrete. In this study, the performance of fly ash based geo polymer concrete was investigated. Initial tests on fine aggregate and coarse aggregate such as specific gravity.From that the optimum ratio of geopolymer concrete was found. It was $85 \%$ fly ash, $14 \%$ silica fume and $1 \%$ nano silica(10MF85S14N1m100) means $10 \mathrm{M}$ Solution, $85 \%$ of Fly Ash, $14 \%$ of Micro Silica, $1 \%$ of Nano Silica, $100 \%$ of M-Sand can be used in this study. Durability test concluded that corrosion resistance has geopolymer concrete less than conventional concrete.[27]

K. Mahendran et al. (2016) the objective of his thesis was to analyse the performance of copper slag as an alternative for fine aggregate in geopolymer concrete. The sand is replaced with copper slag by its weight with an increment of $10 \%$ in each mix M1, M2, up to M11. The strength of the geopolymer concrete having copper slag as a fine aggregate is compared with control concrete found to be 1.35 and 1.51 times increase in strength, when cured it in ambient and oven curing. The maximum compressive strength of oven cured geopolymer concrete is found to be $58.95 \mathrm{Mpa}$ whereas in ambient cured the compressive strength is reduced to $40.78 \mathrm{Mpa}$. It is observed that the percentage of the copper slag has been increased in the geopolymer concrete and the compressive strength also be increased. There is a marginal variation found in the density of the concrete when cured in oven and 
ambient condition. The water absorption of the oven cured geopolymer concrete is found to be minimum when compared with the ambient curing condition. The microstructure of geopolymer concrete shows the homogeneity of the geopolymer concrete and dissolution of fly ash is also found on the specimen surfaces.[28]

S Ganesh Kumar et al. (2016)the objective his thesis was to find out strength and durability characteristics of geopolymer concrete especially in coastal environment by using combination of fly ash, GGBS and M-Sand. The characteristic of fly ash, GGBS and M-Sand is studied and M-Sand was confirmed in Zone-III. In this a Mix Design was adopted using M-25 grade and then a mix proportion of 1:1.31:1.96 was formulated. The target mean compressive strength of M-25 concrete using OPCC was $36 \mathrm{~N} / \mathrm{mm}^{2}$. In GPCM @28 days was attained a compressive strength of $48.66 \mathrm{~N} / \mathrm{mm}^{2}$.Since $8 \mathrm{M}$ concrete using has got $35.2 \%$ above OPCC, $8 \mathrm{M}$ GPCM shall be efficient to use by considering the economical point of view. The target mean tensile strength of M-25 concrete using OPCC was $3.5 \mathrm{~N} / \mathrm{mm}^{2}$. In GPCM @28 days was attained a split tensile strength of $4.086 \mathrm{~N} / \mathrm{mm}^{2}$.Since $8 \mathrm{M}$ concrete using has got $16.74 \%$ above OPCC, $8 \mathrm{M}$ GPCM shall be efficient to use by considering the economical point of view. The target mean Flexural strength of M-25 concrete using OPCC was $5.5 \mathrm{~N} / \mathrm{mm}^{2}$. In GPCM @28 days was attained a Flexural strength of $7.00 \mathrm{~N} / \mathrm{mm}^{2}$. Since $8 \mathrm{M}$ concrete using has got $27.27 \%$ above OPCC, 8M GPCM shall be efficient to use by considering the economical point of view. Durability of GPCM was high, compared to OPCC.[29]

Ahmed Mohmed Ahmed Blash et al. (2016) has investigated the compressive strength of the Geopolymer concrete produced by replacement of Ground-granulated blast-furnace slag (GGBS) with SF (Silica fume) by $0 \%, 20 \%, 40 \%, 60 \%, 80 \%$ and $100 \%$, and its studies carried out in varying molarity. Based on the experimental investigations carried out on geopolymer concretes, it can be concluded that the incorporation of SF in the geopolymer concrete mixes resulted in finer pore structure thus produce low permeability concrete. The geopolymer concretes produced with different combination of SF and GGBS are able to produce structural concretes of high grades (much more than $45 \mathrm{MPa}$ ) by self curing mechanisms only and percentage $40 \%$ of SF to $60 \%$ GGBS. The influences of SF on strength of geopolymer concrete mixes were studied. It has been observed that the decreasing the quantity of SF increase of Compressive strength of geopolymer.[30]

J. Thaarrini et al. (2016) has studied the cost of producing $1 \mathrm{~m}^{3}$ of GPC and OPC are calculated based on the market rates of the ingredients required and compared for socio-economic feasibility. Based on the cost calculations, it was seen that the cost of production of OPC concrete is higher than the cost of production of GPC for higher grades. For M30 grade of GPC concrete the cost of production is marginally $(1.7 \%)$ higher than OPC concrete of the same grade whereas for M50 grade, the cost of OPC concrete is $11 \%$ higher than GPC of same grade. It can be concluded that savings in cost can be attained in the production of Geopolymer concretes of higher grades as well as lower grades with only a marginal difference.[31]

Mahaboob Basha S. et al. (2016)the objective of his thesis was to improve the characteristic strength of geopolymer concrete, replaced with $10 \%, 20 \%, 30 \%, 40 \%$ and $50 \%$ of E-waste and M-sand as a fine aggregates and find out the optimum percentage replacement. The strength of geopolymer concrete was increased with increase in percentage of E-waste up to20\%.The maximum strength obtained for M-sand at 28 days is $36.8 \mathrm{Mpa}$ and the maximum strength is obtained for E-waste at 28 days is $32.2 \mathrm{Mpa}$. In split tensile test the maximum strength of $4.8 \mathrm{~N} / \mathrm{mm}^{2}$ is obtained for $20 \%$ replacement of E-waste in concrete at 28 days. For M-sand the split tensile strength is increased up to $50 \%$ replaced in concrete. By adding the polypropylene fibres to concrete it reduces the water permeability and shrinkage and improves tensile strength of concrete by adding polypropylene fibres to concrete.[32]

NamitaPatiyal et al. (2016) has investigated to found out the effectiveness of used foundry sand as a partial replacement of fine aggregate in geopolymer concrete. The percentage of replacement are $0 \%$, $5 \%, 10 \%, 15 \%, 20 \%$ and $25 \%$ by weight of fine aggregate by waste foundry sand. The silica ash GGBS based geopolymer concrete gained strength with earlier time period through oven curing at $80^{\circ} \mathrm{C}$. The 7 days and 28 days maximum compressive strength of respectively $20.90 \mathrm{~N} / \mathrm{mm}^{2}$ and $28.33 \mathrm{~N} / \mathrm{mm}^{2}$ was also obtained for $15 \%$ replacement of fine aggregate and found out the optimum percentage for replacement of foundry sand with natural sand is almost $15 \%$ for cubes.The 7 days and 28 days maximum split tensile strength of respectively $2.92 \mathrm{~N} / \mathrm{mm}^{2}$ and $4.23 \mathrm{~N} / \mathrm{mm}^{2}$ was also obtained 
for $10 \%$ replacement of fine aggregate and found out the optimum percentage for replacement of foundry sand with natural sand is almost $10 \%$ for cylinders. The 7 days and 28 days Flexural strength of respectively $5 \mathrm{~N} / \mathrm{mm}^{2}$ and $5.83 \mathrm{~N} / \mathrm{mm}^{2}$ was obtained for $10 \%$ replacement of fine aggregate and found out the optimum percentage for replacement of foundry sand with natural sand is almost $10 \%$ for cylinders.[33]

G. Gayathri et al. (2016) has studied to produce the geo-polymer concrete the Portland cement is fully replaced by fly ash and GGBS (Ground granulated blast furnace slag). Fly ash and GGBS were used in this study such as $90 \%$ fly ash and 10\% GGBS and studied to cover the use of E-Waste as partial replacement in fine aggregate in geopolymer concrete. The main objective of his thesis was to investigate the change in mechanical properties of geopolymer concrete with E-Waste in concrete and reduce as far as possible the accumulation of used and discarded electronic and electrical equipments and investigated with replacement of sand by using e-waste are $0 \%, 10 \%, 20 \%, 30 \%, 40 \%$ and $50 \%$.The initial setting time with 90 percent fly ash +10 percent GGBS obtained as 19.9 hours the normal consistency obtained at 28 percentages. Use of E-waste as partial replacement of fine aggregate is economical. 30\% Partial replacement of E-waste as fine aggregate proved as well graded aggregate.[34]

P. Pavani et al. (2016) the objective of his thesis was to study the strength properties of class $\mathrm{F}$ fly ash (FA) based geo polymer concrete (GPC) using granite slurry powder (GS) as sand replacement at different levels $(0 \%, 20 \%$ and $40 \%)$ and investigated to study the engineering properties of GPC (FA50-GGBS50) viz. $\mathrm{FA}_{50}-\mathrm{GGBS}_{50}-\mathrm{GS}_{0}, \mathrm{FA}_{50}-\mathrm{GGBS}_{50}-\mathrm{GS}_{20}$ and $\mathrm{FA}_{50}-\mathrm{GGBS}_{50}-\mathrm{GS}_{40}$ are considered. It is concluded that the increased replacement level of granite slurry powder (GS) increased the compressive strength, splitting tensile strength values of GPC mixes. Maximum compressive strength and splite tensile strength of geopolymer concrete are $42.14 \mathrm{~N} / \mathrm{mm}^{2}, 56.32 \mathrm{~N} / \mathrm{mm}^{2}, 68.36 \mathrm{~N} / \mathrm{mm}^{2}$ and $2.75 \mathrm{~N} / \mathrm{mm}^{2}, 3.61 \mathrm{~N} / \mathrm{mm}^{2}, 4.6 \mathrm{~N} / \mathrm{mm}^{2}$ respectively for 7 days, 28 days and 90 days.FA ${ }_{50}-\mathrm{GGBS}_{50}-\mathrm{GS}_{40}$ is optimum replacement.[35]

Based on previous research review, history related to the use of industrial waste materials for making of Geopolymer concrete is shown in figure 1.

\section{HISTORICAL DEVELPMENT RELATED TO USE OF INDUSTRIAL WASTE}

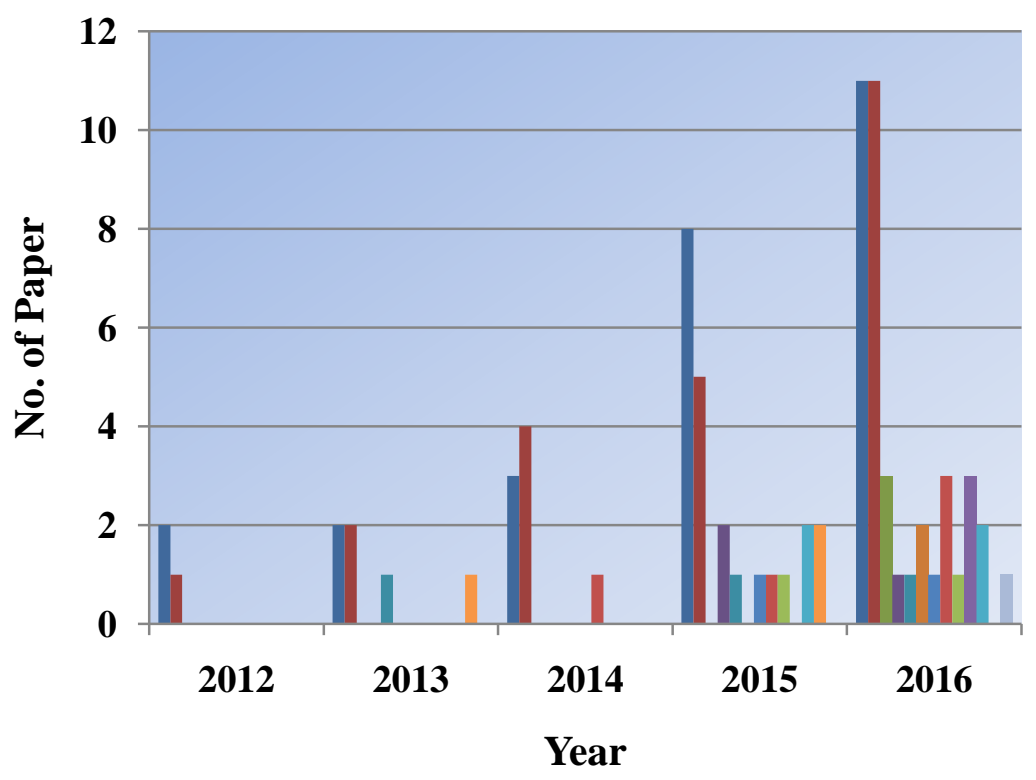

Fly Ash
GGBS
E-Waste
Granite Slurry
Bottom Ash
Copper Slag
Waste Glass Powder
Micro Silica
Nano Silica
M-Sand
Foundry Sand
Steel Slag
Polypropelene Fibre

Figure1. History of use of industrial waste material

\section{CONCLUSION}

The Literature review based on Using Industrial waste in Geopolymer concrete concluded that by using various Industrial waste materials as a partial substitute of fine aggregate, coarse aggregate, 
cement and sand of design mix in Geopolymer concrete, overall cost of making of Geo polymer concrete can reduce.

1) It can reduce the disposal problems of Industrial waste materials and also consume the cement used for making of Geo polymer concrete.

2) Different tests have been conducted as per the standards on the Geopolymer concrete. The common parameter calculated by various researchers is compressive strength.

3) It is seen that waste materials like fly ash, GGBS, Micro silica were used extensively and sufficient research have been done on them.

4) When cement is replaced by various industrial waste compressive strength, flexural strength and split tensile strength of Geo polymer concrete for various mixes is depends upon the type of Industrial waste materials used for making of Geo polymer concrete.

5) The study in turn is useful for various resource persons involved in using industrial or agricultural waste material to develop sustainable construction material.

\section{ACKNOWLEDGMENT}

The Authors thankfully acknowledge to Dr. C. L. Patel, Chairman, Charutar Vidya Mandal, Er. V. M. Patel, Hon.Jt. Secretary, Charutar Vidya Mandal, Mr. Yatinbhai Desai, Jay Maharaj construction, Prof (Dr.) Indrajit N. Patel, Principal, B.V.M. Engineering College, Dr. L.B.Zala, Head and Professor, Civil Engineering Department, Prof. J. J. Bhavsar, Associate Professor, Civil Engineering Department, B.V.M. Engineering College, Vallabh Vidyanagar, Gujarat, India for their motivations and infrastructural support to carry out this research.

\section{REFERENCES}

[1] DhirajAgrawal, Pawan Hinge, U. P. Waghe, S.P. Raut, "Utilization of industrial waste in construction material - A review", International Journal of Innovative Research in Science, Engineering and Technology, ISSN: 2319-8753, Vol. 3, Issue 1, January 2014.

[2] Rohit Kumar1 and Dr. Mayengbam Sunil Singh, "Alternate Cementitious Material: Geopolymer Concrete", Conference Info., National Conference on Innovations in Science and Technology (NCIST-17), Sponsored by AICTE-NEQIP), ISBN: 978-81-933746-4-1.

[3] Dharani.J\&Dharmar.S, "Strength Of Geopolymer Concrete By Using Mineral Admixtures: A Review", SSRG International Journal of Civil Engineering- (ICRTCETM-2017), ISSN: 2348 - 8352,Special Issue, April 2017.

[4] Ganapati Naidu. P, A.S.S.N.Prasad, S.Adiseshu, P.V.V.Satayanarayana, “A Study on Strength Properties of Geopolymer Concrete with Addition of G.G.B.S", International Journal of Engineering Research and Development, eISSN : 2278-067X, pISSN : 2278-800X, Volume 2, Issue 4, PP. 19-28.

[5] Prof. M. A. Bhosale, Prof. N. N. Shinde " Geopolymer Concrete by Using Fly Ash in Construction”, IOSR Journal of Mechanical and Civil Engineering, ISSN: 2278-1684 Volume 1, Issue 3, PP 25-30.

[6] Mr. Bennet Jose Mathew, Mr. M Sudhakar, Dr. C Natarajan, "Strength, Economic and Sustainability Characteristics of Coal Ash -GGBS Based Geopolymer Concrete", International Journal Of Computational Engineering Research, ISSN 2250-3005, Vol. 3 Issue. 1.

[7] Ravindra Singh Shekhawat, RanjitParsad, Sanjay Kumar, "Mechanical Behaviour of Steel Slag based Geopolymer Concrete", ResearchGate, publication/309742115.

[8] B. Rajini, A.V. NarasimhaRao, "Mechanical Properties of GeopolymerConcrete with Fly Ash and GGBS as Sources Materials", International Journal of Innovative Research in Science,Engineering and Technology, ISSN: 2319-8753, Vol. 3, Issue 9.

A. Rajerajeswari, G. Dhinakaran, Mohamed Ershad, "Compressive Strength of Silica Fume based Geo polymer Concrete", Asian Journal of Applied Science, ISSN: 1996-3343.

[9] T.V. Srinivas Murthy, Dr. Ajeet Kumar Rai, "Geopolymer Concrete, an Earth Friendly Concrete, Very Promisinginthe Industry", international journal of civil engineering and technology, ISSN $0976-6308$ (Print), ISSN 0976 6316(Online), Volume 5, Issue 7, pp. 113-122.

[10] L.Krishnan, S.Karthikeyan, S.Nathiya, K. Suganya, "Geopolymer Concretean Eco-friendly Construction Material", International Journal of Research in Engineering and Technology, eISSN: 2319-1163 | pISSN: 2321-7308, Volume: 03 Special Issue: 11.

[11] C. Sreenivasulu, A. Ramakrishnaiah and J. Guru Jawahar, "Mechanical Properties of Geopolymer Concrete using Granite Slurry as Sand Replacement" ,International Journal of Advances in Engineering \& Technology, ISSN: 22311963, Vol. 8, Issue 2, pp. 83-91. 
[12] Jerusha Susan Joy, Dr. Mini Mathew, "Experimental Study on Geopolymer Concrete with Partial Replacement of Fine Aggregate with Foundry Sand", International Journal of Advanced Technology in Engineering and Science, ISSN: 2348-7550, Vol.No.3, Special Issue No.1.

[13] Janardhanan Thaarrini, Venkatasubramani Ramasamy, "Properties of Foundry Sand, Ground Granulated Blast Furnace Slag and Bottom Ash Based Geopolymers under Ambient Conditions", Periodica Polytechnica Civil Engineering, 60(2), pp. 159-168, 2016, DOI: 10.3311/PPci.8014.

[14] Shalika Sharma, "Abrasion Resistance of Geopolymer Concrete with the Change in Curing Time and Curing Temperature", International Journal of Computational Engineering Research, ISSN (e): 2250 3005, Volume.05 Issue. 12

[15] O. M. Omar, A. M. Heniegal, G. D. Abd Elhameed, H. A. Mohamadien, "Effect of Local Steel Slag as a Coarse Aggregate on Properties of Fly Ash Based-Geopolymer Concrete", International Journal of Civil, Environmental, Structural, Construction and Architectural Engineering, Vol:9, No:11.

[16] Yagnesh Patel, Dr. Indrajit N Patel, Mrs. Jagruti Shah, "Experimental Investigation on Compressive Strength and Durability Properties of Geopolymer Concrete Incorporating with nanosilica", international journal of civil engineering and technology, ISSN 0976 - 6308 (Print), ISSN 0976 - 6316(Online), Volume 6, Issue 5, pp. 135-143

[17] Shalika Sharma, "Change in the Compressive Strength of Geopolymer Concrete with the Change in the Curing Time and Curing Temperature", International Journal of Emerging Technology and Advanced Engineering, ISSN 2250-2459, Volume 5, Issue 12.

[18] Dr. I.R. Mithanthaya, Dr. N. Bhavanishankar Rao, "Effect of Glass Powder and GGBS on Strength of Fly Ash Based Geopolymer Concrete", International Journal of Engineering Trends and Technology, ISSN: 2231-5381, Volume 19 Number 2.

[19] Nitendra Palankar a, A U Ravi Shankar b, Mithun B M, "Studies on Eco-friendly Concrete Incorporating Industrial Waste as Aggregates”, Researchgate, publication/278050061.

[20] P. VenkataAvanthiSailalasa, M. Srinivasula Reddy, “A Study on Granite Saw Dust \& Fly Ash Blended Geopolymer Concrete Behavior with Various $\mathrm{NaOH}$ Molarities", International Journal of Science and Research, ISSN (Online): 2319-7064, Paper ID: SUB158162, Volume 4, Issue 9.

[21] M Lenin Sundar, SherineRaj, M Vadivel, "Experimental Investigation of Geopolymer Concrete with EWaste", International Journal of Earth Sciences and Engineering ISSN 0974 5904, Vol. 09, No. 03, pp. 491-496.

[22] P Abhilash, C.Sashidhar, I.V.Ramana Reddy, "Strength properties of Fly ash and GGBS based Geopolymer Concrete", International Journal of ChemTech Research, ISSN: 0974-4290,Vol.9, No.03 pp 350356

[23] Neethu Susan Mathew, S. Usha, "Effects of Copper Slag as Partial Replacement for Fine Aggregate in Geopolymer Concrete", IOSR Journal of Mechanical and Civil Engineering, e-ISSN: 2278-1684,p-ISSN: 2320-334X, PP 73-77.

[24] ShriramMarathe, Pushparaj, Ravikiran N, "Laboratory Investigation on the Strength and

[25] Durability Characteristics of Geopolymer Concrete", International Journal of Innovative Research in Science, Engineering and Technology, ISSN(Online) : 2319 8753, ISSN (Print) : 2347-6710, Vol. 5, Special Issue 9.

[26] R. B.Sheral, D. Sutar, P. Jagdane, "Utilization of Waste Materials (GGBS+FLY ASH)", International Journal of Latest Technology in Engineering,Management\& Applied Science, ISSN 2278-2540, Volume $\mathrm{V}$, Issue VII.

[27] M BalaVinayag, M.I. Abdul Aleem, " Strength \& Durability Characteristic of geo polymer concrete with Micro silica Nano Silica and m-Sand", International Journal of Innovations in Engineering \& Management,ISSN:2319-1058,Volume-7,Issue-1.

[28] K. Mahendran and N. Arunachelam, "Performance of Fly Ash and Copper Slag based Geopolymer Concrete", Indian Journal of Science and Technology, ISSN (Print): 0974-6846, ISSN (Online): 09745645, Vol 9(2), DOI: 10.17485/ijst/2016/v9i2/86359.

[29] S Ganesh Kumar, S Dinesh, Dr M I Abdul Aleem, "Feasability Study on the use of Geo polymer Concrete in Coastal Environment", International Journal of Latest Trends in Engineering \&Technology, ISSN: 2278-621X.

[30] Ahmed Mohmed Ahmed Blash, Dr. T.V. S. Vara Lakshmi, "Properties of Geopolymer Concrete Produced by Silica Fume and Ground-Granulated Blast-Furnace Slag", International Journal of Science and Research, Paper ID: ART20162136, ISSN (Online): 2319-7064, Volume 5 Issue 10.

[31] J.Thaarrini\&S.Dhivya, " Comparative Study on the Production Cost of Geopolymer and Conventional Concretes”, International Journal of Civil Engineering Research, ISSN 2278-3652 Volume 7, Number 2, pp. $117-124$ 
[32] MahaboobBasha S, Bhupal Reddy Ch,Vasugi K, "Strength behaviour of geopolymer concrete replacing fine aggregates by M- sand and E-waste", International Journal of Engineering Trends and Technology, ISSN: 2231-5381, Volume-40 Number-7.

[33] NamitaPatiyal, Jitender Kumar, Abhilesh Kant Sharma, "Experimental Study on Geopolymer Concrete with Partial Replacement of Fine Aggregate with Foundry Sand", International Journal of Recent Research Aspects, ISSN: 2349-7688, Vol. 3, Issue 2, pp. 133-138.

[34] G.Gayathri, V.S.Ramya, T.Yasothaand M.Dheenedhayalan, "ExperimentalInvestigationon Geopolymer Concrete with E-Waste", International Journal of Research and Reviews in Applied Sciences and Engineering, ISSN: 2231-0061, Vol 8. No.2, Pp.280-291.

[35] P. Pavani, A.Roopa, Dr. J. Guru Jawahar, C. Sreenivasulu, “ Investigation on Geopolymer Concrete using Granite Slurry Powder as PartialReplacement of Fine Aggregate", International Research Journal of Engineering and Technology, e-ISSN: 2395 -0056, p-ISSN: 2395-0072, Volume: 03, Issue: 06.

\section{AUTHORS' BIOGRAPHY}

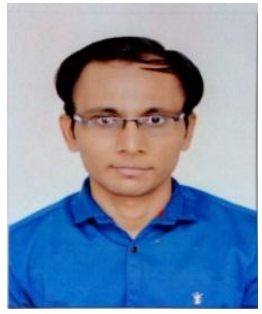

Bhavik kumar B. Patel, received his Bachelor of Engineering degree in Civil Engineering from the ShankersinhVaghelaBapu Institute of Technology, Gujarat Technological University in 2016. At present, he is final year student of Master of Technology in Construction Engineering \& Management from Birla Vishvakarma Mahavidyalaya, Gujarat Technological University. He has paper presented in National Conference. He has paper published in international journal.

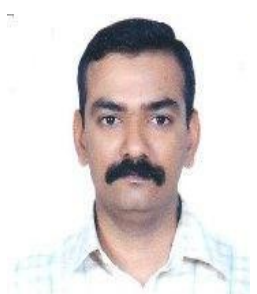

Dr. Jayeshkumar R Pitroda, received his bachelor of engineering degree in Civil Engineering from Birla Vishwakarma Mahavidyalaya Engineering College, Sardar Patel University in 2000. In 2009 he received his master's degree in Construction Engineering and Management from Birla Vishwakarma Mahavidyalaya Sardar Patel University. In 2015 he received his Doctor of philosophy (Ph.D.) degree in Civil Engineering from Sardar Patel University. He joined Birla Vishwakarma Mahavidyalaya Engineering College as a faculty in 2009, where he is Assistant Professor of Civil Engineering Department with a total experience of 17 years in the field of research, designing, and education. He is guiding M.E. (Construction Engineering and Management) thesis work in the field of Civil / Construction Engineering. He has published many papers in National / International Conferences and National / International Journals. He has published seven Research Books in the field of Civil Engineering, Rural Road Construction, National Highways Construction, Utilization of Industrial Waste, Fly Ash Bricks, Construction Engineering and Management, Ecofriendly Construction.

Citation: Dr. Jayeshkumar Pitroda et.al. (2017) A Review of Geo Polymer Concrete by Using Various Industrial Waste Materials, International Journal of Constructive Research in Civil Engineering, 3(4), pp.121-131. DOI: http://dx.doi. org/10.20431/2454-8693.0304011

Copyright: (C) 2017 Dr. Jayeshkumar Pitroda, This is an open-access article distributed under the terms of the Creative Commons Attribution License, which permits unrestricted use, distribution, and reproduction in any medium, provided the original author and source are credited. 